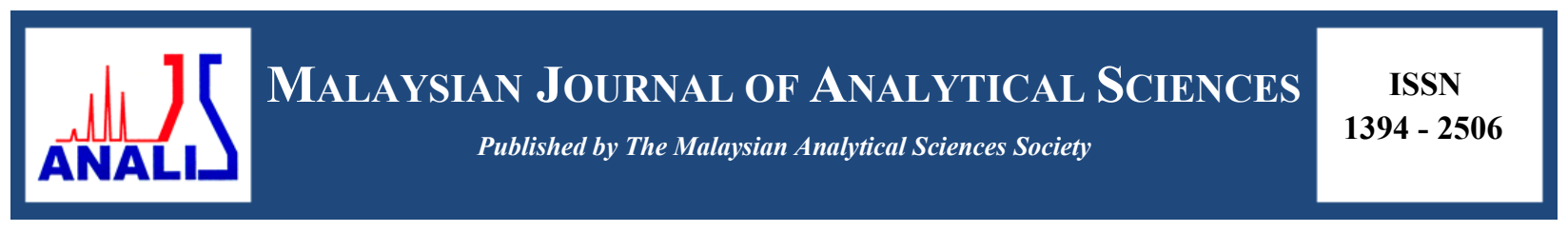

\title{
ANALYSIS OF Sesquiterpenes IN AGARWOOD ESSENTIAL OIL FROM HYDRODISTILLATION PROCESS
}

\author{
(Analisis Sesquiterpenes di dalam Pati Minyak Gaharu daripada Proses Penyulingan Air) \\ Nurhaslina Che Radzi*, Mohamad Khir Zahari Harip, Mohibah Musa, Nurul Asyikin Md Zaki, Habsah Alwi, \\ Miradatul Najwa Muhd Rodhi, Ku Halim Ku Hamid \\ Faculty of Chemical Engineering, \\ Universiti Teknologi MARA, 40450 Shah Alam, Selangor, Malaysia \\ *Corresponding author: nurhaslina483@salam.uitm.edu.my
}

Received: 15 February 2017; Accepted: 2 January 2018

\begin{abstract}
Agarwood or its specific named, Aquilaria spp. is a precious tree in the world. It has been used widely in pharmaceutical industry, production of perfumes and incense raw material. In this study, the agarwood essential oil, species of Aquilaria maleccensis is being extracted by using hydrodistillation method. This study aims to analyse the present of chemical compound named sesquiterpenes in the agarwood essential oil. The effect of pre-treatment using soaking process on the agarwood within 7 days, 14 days and 21 days before proceed for hydrodistillation process had been done. The hydrodistillation process took 3 days before the sample of essential oil is collected. The sample is being analysed by using gas chromatography mass spectrometry (GC-MS). The result showed the existence of sesquiterpenes had been identified from all sample of three batches. However, different types of sesquiterpenes were identified for different batch. The highest sesquiterpenes content for $1^{\text {st }}$ batch is $\alpha$ gurjunene with $2.95 \%$, the $2^{\text {nd }}$ batch is ç-Himachalene with $0.292 \%$ and the $3^{\text {rd }}$ batch is same with the $1^{\text {st }}$ batch which is $\alpha$ gurjunene with $0.356 \%$.
\end{abstract}

Keywords: agarwood, Aquilaria maleccensis, Sesquiterpenes, hydrodistillation, gas chromatography mass spectrometry

Gaharu atau nama spesifiknya, Aquilaria spp. adalah pokok yang sangat berharga di dunia. Ia banyak digunakan di dalam industri farmaseutikal, penghasilan minyak wangi dan bahan asas kemenyan. Dalam kajian ini, pati minyak gaharu, jenis Aquilaria maleccensis di ekstrak melalui kaedah penyulingan air. Tujuan kajian ini adalah untuk menganalisis kehadiran komponen kimia yang dinamakan sebagai sesquiterpenes di dalam pati minyak gaharu. Kesan pra rawatan menggunakan proses rendaman ke atas gaharu dilakukan antara 7 hari, 14 hari dan 21 hari sebelum dilanjutkan ke proses penyulingan air. Proses penyulingan air mengambil masa 3 hari sebelum sampel pati minyak gaharu diambil. Sampel tersebut tersebut seterusnya dianalisis menggunakan kromatografi gas spektrometri jisim (GC-MS). Keputusan menunjukkan kehadiran sesquiterpenes daripada ketiga-tiga kumpulan. Walau bagaimanapun, jenis sesquiterpenes berbeza dikenalpasti bagi setiap kumpulan. Kuantiti sesquiterpenes paling tinggi dalam kumpulan pertama ialah $\alpha$-gurjunene iaitu $2.95 \%$, kumpulan kedua ialah ç-Himachalene iaitu sebanyak $0.292 \%$ dan kumpulan ketiga adalah bersamaan dengan kumpulan pertama iaitu $0.356 \%$.

Kata kunci: gaharu, Aquilaria maleccensis, Sesquiterpenes, penyulingan air, kromatografi gas spektrometri jisim 


\section{Introduction}

Agarwood has been known and used a long time ago as medicinal properties in pharmaceutical, incense, in religious practices and mostly perfume [1]. In Malaysia, agarwood commonly known as gaharu, is a tree of the genus Aquilaria spp. belongs taxonomically to the Thymelaeaceae family. It has various known species which is more than 15 species and can be categorized into 4 grades; A, B, C and D referring to its physical properties, formation and scent. Most previous study about agarwood is focused on the extraction of essential oil [2]. There are many ways to extract the essential oil from agarwood such as supercritical fluid extraction, solvent extraction, hydrodistillation and others. In this study, hydrodistillation method has been used because it is commonly used in industry to extract essential oils. Hydrodistillation method also is low cost, simplest and easy to construct. However, using this method, the oil yield is very low [1].

Therefore, the pre-treatment process had been introduced in order to enhance the essentials oil yield. There are several methods to pre-treat plant sample from previous study before extraction such as chemical treatment, soaking in water and sonication. Some studies focused on the pre-treatment process in order to increase the oil yield which is similarly to this study. For this pre-treatment process, agarwood was soaked by tap water. Previous study by Veronica et. al [1] on the effects of soaking time showed different quality of essential oils yield. There are many studies about pharmacological properties on the agarwood essential oil especially in anti-inflammatory [3], antioxidant [4], antibacterial [5], anti-hyperglycemic [6] and anti-ischemic [7]. However, only few research had been done for the identification of sesquiterpenes which believe have a potential to cure cancer. Hence, this study will be focused on pharmacological properties which had been identified as a secondary compound in the agarwood essential oil called sesquiterpenes. This sesquiterpenes is believed can act as anti-cancer agent. The presence of sesquiterpenes in the agarwood essential oil will be analysed using gas chromatography mass spectrometry GC-MS. Therefore, this study aim to analyze an effect of pre treatment towards types of sesquiterpenes exist in agarwood essential oil.

\section{Sample collection and preparation}

\section{Materials and Methods}

The raw agarwood species of Aquilaria Maleccensis were obtained from Taiping, Perak. Pretreatment process which is soaking the $25 \mathrm{~kg}$ agarwood chips with tap water was run within 7 days $\left(1^{\text {st }}\right.$ batch), 14 days $\left(2^{\text {nd }}\right.$ batch) and 21 days $\left(3^{\text {rd }}\right.$ batch). Before proceed to hydrodistillation process, the agarwood chips need to be drying first by using solar (sun). Then, every batch of agarwood chips is fully immersed into the water for hydrodistillation process. The essential oils of agarwood were collected once after the oils have been extracted via hydrodistillation process that will undergo for 3 days. The sample of oils were analysed to determine the existence of sesquiterpenes properties.

\section{Gas chromatography mass spectrometry analysis}

The sesquiterpenes properties in the sample of agarwood essential oils were identified by using GC-MS (Varian Inc.). Separation of analytes by gas chromatography was carried by using silica DB-1 capillary column ( $30 \mathrm{~m} \times 0.25$ $\mathrm{mm} \times 0.25 \mathrm{~mm}$ ). The oven temperature was programmed to $80{ }^{\circ} \mathrm{C}$ for 2 minutes. Then, the temperature increased 10 ${ }^{\circ} \mathrm{C} / \mathrm{min}$ until $250^{\circ} \mathrm{C}$. The retention time selected was 50 minutes. Helium was used as carrier gas with a constant gas flow rate of $2 \mathrm{ml} / \mathrm{min}$. Electron impact were measured at acceleration energy of $70 \mathrm{eV}$. Injection volume of $1 \mu \mathrm{l}$ of the sample was performed in the split mode used at a 50:1 split ratio $[8,9]$.

\section{Results and Discussion}

The results of existence compound sesquiterpenes from all sample among 3 batches were obtained after being analysed by using GC-MS. Figure 1 (a) - (c) show the result of chemical compound of agarwood oil from $1^{\text {st }}, 2^{\text {nd }}$ and $3^{\text {rd }}$ batch, respectively. 

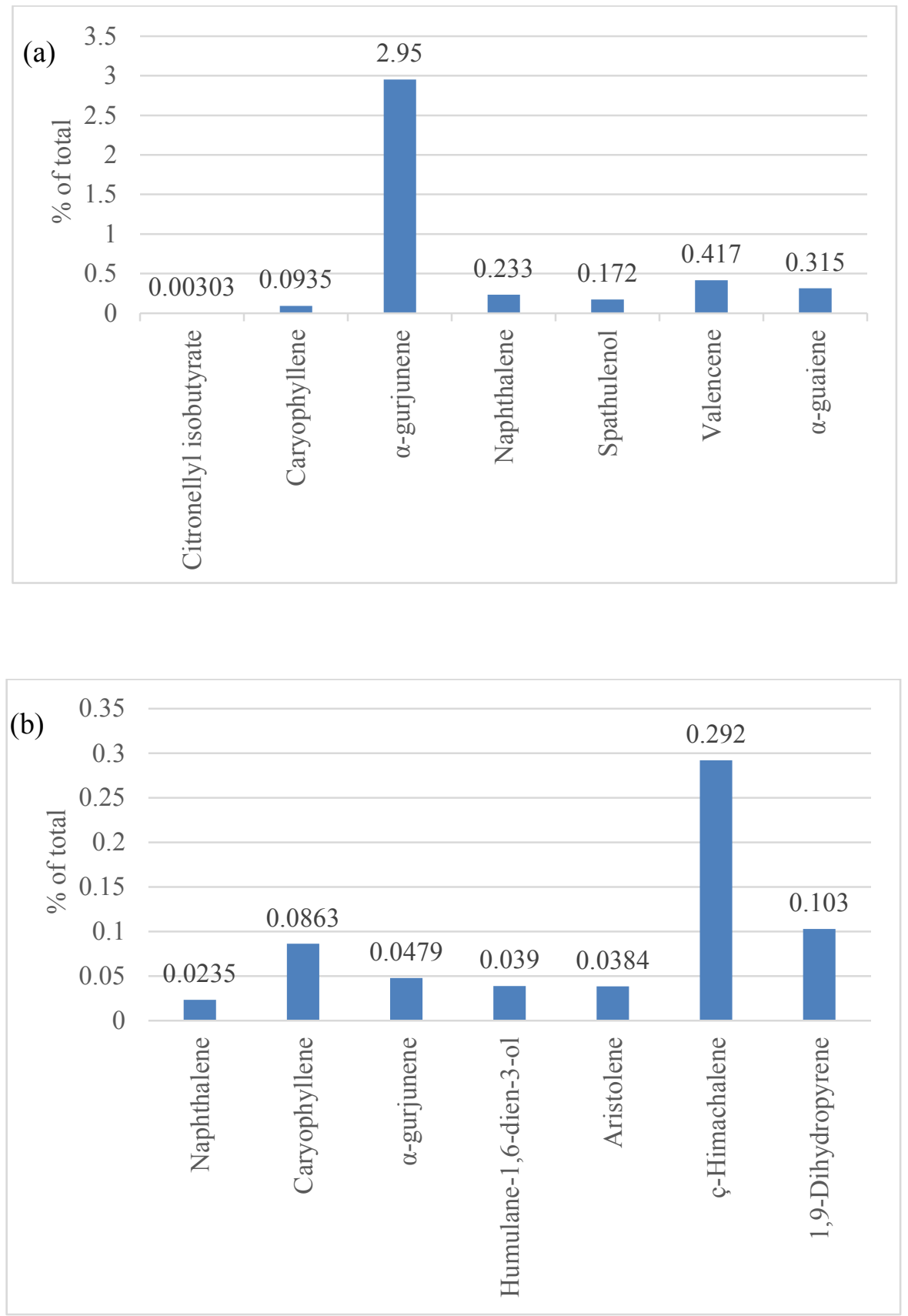


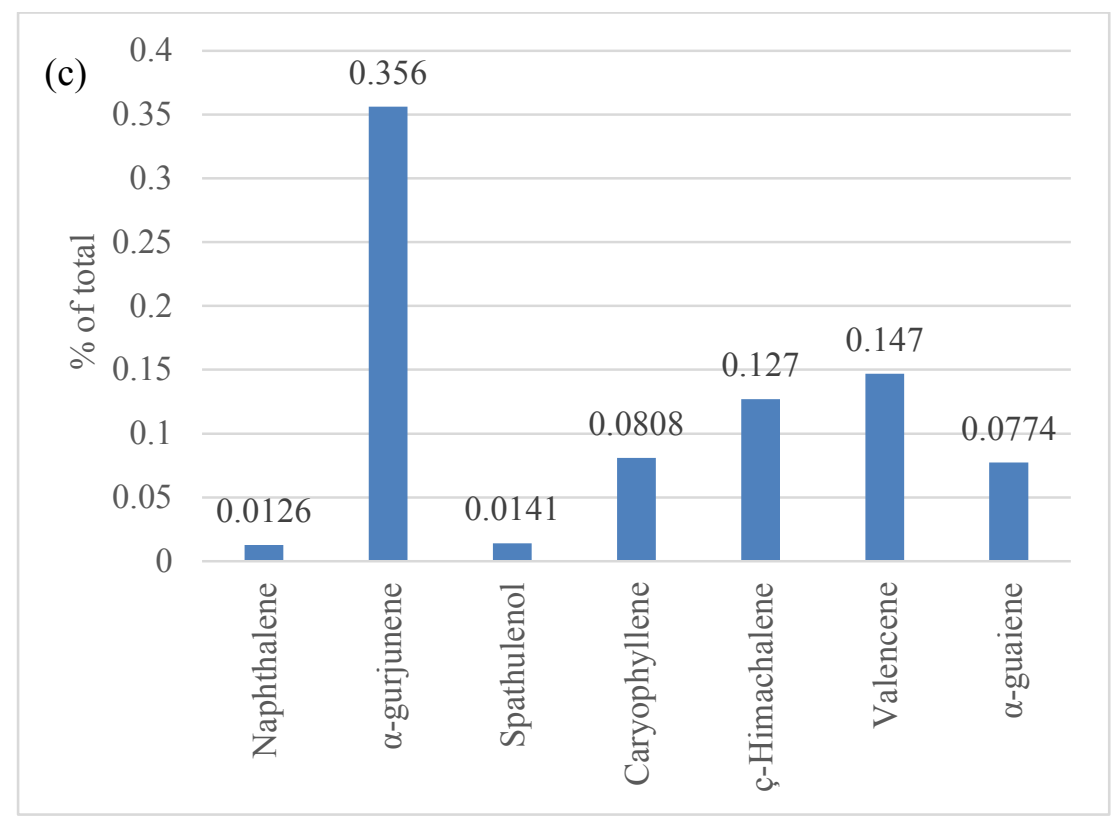

Figure 1. Chemical compound of agarwood oil in (a) $1^{\text {st }}$ batch, (b) $2^{\text {nd }}$ batch and (c) $3^{\text {rd }}$ batch

The results show that there were several major types of sesquiterpenes obtained from the agarwood oil from all three batches such as $\alpha$-gurjunene, $\alpha$-guaiene, aristolene, ç-Himachalene, caryophyllene and others. The average percentage content of sesquiterpenes found in all three batch were about $2 \%$. The chemical composition of the agarwood essential oil may result in difference composition by several factors which are species of the agarwood tree, pre-treatment and extraction method used for agarwood essential oil [10]. This can be proved by Figure 1(a) (c) that showed different types of sesquiterpenes were identified among three batches. The $1^{\text {st }}$ batch obtained sesquiterpenes of Citronellyl isobutyrate which is not identified in the $2^{\text {nd }}$ batch and $3^{\text {rd }}$ batch. Then, the $2^{\text {nd }}$ batch obtained sesquiterpenes of Humulane-1,6-dien-3-ol, Aristolene and 1,9-Dihydropyrene which are not identified in the $1^{\text {st }}$ batch and $3^{\text {rd }}$ batch. Besides that, this also can be proved in the previous study which is several different types of sesquiterpenes were found in agarwood of Aquilaria Sinensis species [11]. The soaking activity for pre-treatment also shows the effect towards the quality of agarwood oil. Soaking process was conducted during agar wood essential oil extraction, which contributes to the opening and enlargement of pore size on agar wood structure as well as the oil yield percentage. Soaking in water should then be one of the unit operations to extract essential oil from agar wood. To disturb the structure of the cell wall, the environment and surrounding condition need to be changed or altered by introducing to acidic or alkali solvent to allow the movement desired compounds from high to low concentration. By altering the external and internal factors, it can contribute the secretion of compound to the soaked water environment [1]. During soaking process, the cell has expanded and finally burst, thus releasing the content out to the soaking medium. The solvent enters cell wall by simple diffusion and increase the turgor pressure. The solvent becomes more acidic along the time due to the released compounds and corrodes the cell wall. It damages the structure of the cell wall. However, too long soaking time causes more compounds content wasted to the solvent. The soaked agarwood give higher yield of essential oil compared to non-soaked agarwood [12].

Hence, the results for this study from GC-MS analysis showed different types of sesquiterpenes were found among three batches. However, further study need to be done to confirm the presence of the sesquiterpenes content in agarwood oil such as by using other analysis method namely high performance liquid chromatography (HPLC) and Fourier transform infrared (FTIR). 


\section{Conclusion}

The analysis of sesquiterpenes from agarwood essential oil using GC-MS is successfully carried out. The results show that several types of sesquiterpenes compound were identified. The quality of essential oil also may varies based on the chemical compound. Pre-treatment by soaking activity at optimum time prove to produce higher yield and more compound extracted compared to non-soaking activity. Further studies are needed to refine the results which later can be used to assist and improve pharmaceutical industry especially for curing cancer.

\section{Acknowledgement}

The authors want to express special gratitude to Universiti Teknologi MARA, UiTM Shah Alam, specifically to Faculty of Chemical Engineering for allowing the usage of facilities especially for all the laboratory instrument. Many thanks to all who have been directly and indirectly assisted this research.

\section{References}

1. Jok, V. A., Che Radzi, N. and Ku Hamid, K. H. (2015). Agarwood oil yield as a result of changes in cell morphology due to soaking process. Procedia-Social and Behavioral Sciences, 195: 2443-2450.

2. Zainuddin, N. A. S., Ismail, K. N., Ku hamid, K. H., Muhd Rodhi, M. N. and Musa, M. (2013). Analysis of agarwood waste at different pre-treatment for silica xerogel production. Advanced Materials Research 709: 915-918.

3. Zhou, M., H. Wang, S., Kou, J. and Yu, B. (2008). Antinociceptive and anti-inflammatory activities of Aquilaria sinensis (Lour.) Gilg. leaves extract. Journal of Ethnopharmacology, 117: 345-350.

4. Sattayasai, J., Bantadkit, J., Aromdee, C., Lattmann, E. and Airarat, W. (2012). Antipyretic, analgesic and antioxidative activities of Aquilaria crasnna leaves extract in rodents. Journal of Ayurveda and Integrative Medicine, 3(4): 175-179.

5. Kamonwannasit, S., Nantapong, N., Kumkrai, P., Luecha, P., Kupittayanant, S. and Chudapongse, N. (2013). Antibacterial activity of Aquilaria crasnna leaf extract against Staphylococcus epidermidis by disruption of cell wall. Annals of Clinical Microbiology and Antimicrobials, 12(1): 20.

6. Pranakhon, R., Pannangpetch, P. and Aromdee, C. (2011). Antihyperglycemic activity of agarwood leaf extracts in STZ-induced diabetic rats and glucose uptake enhancement activity in rat adipocytes. Songklanakarin Journal of Science \& Technology, 33(4):405-410.

7. Suwannasing, C., Paiyabhroma, N. and Kumphune, S. (2012). Anti-ischemic effect of ethyl acetate extract of Aquilaria crasnna by attenuation of p38-MAPK activation. Journal of Applied Pharmaceutical Science 2(10): 026-030.

8. Chen, Y., Wu, Y-G., Xu, Y., Zhang, J-F., Song, X-Q., Zhu, G-P. and Hu, X-W. (2014). Dynamic ccumulation of sesquiterpenes in essential oil of Pogostemon cablin. Revista Brasileira De Farmacognosia-Brazilian Journal of Pharmacognosy 24(6): 626-634.

9. Yumi Z., Hashim, H-Y., Ismail, N. I. and Abbas, P. (2014). Analysis of chemical compounds of agarwood oil from different species by gas chromatography mass spectrometry (GCMS). IIUM Engineering Journal 15: 55-60.

10. Mohd Ali, N. A., Ismail, N. and Taib, M. N. (2012). Analysis of agarwood oil (Aquilaria malaccensis) based on GC-MS data. IEEE $8^{\text {th }}$ International Colloquium on Signal Processing and its Applications: 470-473.

11. Li, W., Cai, C-H., Guo, Z-K., Wang, H., Zuo, W-J.,Dong, W-H., Mei, W-L. \& Dai, H-F. (2015). Five new eudesmane-type sesquiterpenoids from Chinese agarwood induced by artificial holing. Fitoterapia 100: 44-49.

12. Muhammad Fadzil, A. H., Ku Halim, K. H. and Muhd Rodhi, M. N. (2013). Extraction of essential oil from biologically inoculated agarwood. IEEE Business Engineering and Industrial Applications Colloquium: 889892. 